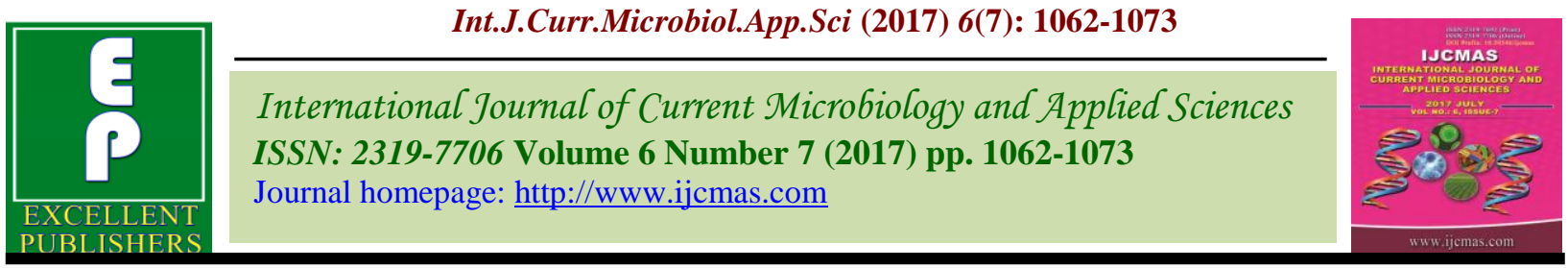

Original Research Article

https://doi.org/10.20546/ijcmas.2017.607.128

\title{
Comparative Analysis of Vulnerability Indices and its Implications: A Case of Kosi Region (Bihar), India
}

\author{
Meera Kumari* and Jyoti Bharti \\ Department of Agricultural Economics, BAU, Sabour, Bhagalpur, Bihar - 813210, India \\ *Corresponding author
}

\section{A B S T R A C T}

\begin{tabular}{|l|}
\hline Ke y w o r d s \\
Climate change, \\
Sensitivity, \\
Adaptive capacity, \\
Vulnerability and \\
Kosi Region. \\
\hline Article Info \\
\hline $\begin{array}{l}\text { Accepted: } \\
\text { 17 June } 2017 \\
\text { Available Online: } \\
\text { 10 July } 2017\end{array}$ \\
\hline \hline
\end{tabular}

The study was planned to construct vulnerability index and compare different districts of the delineated area in relation to vulnerability index. For this purpose a composite vulnerability index was developed, emphasizing on the three major components namely, (i) Exposure (ii) Sensitivity and (iii) Adaptive capacity. The results of investigation revealed that, in the year 1976-1985 the district of Kishanganj ranked first and the district of Araria ranked last (8th) in the overall vulnerability to climate change. The agricultural sector played a significant role in ranking Kishanganj district at the first position contributed to the tune 34.67 per cent to the overall vulnerability followed by occupational 28.96 per cent, climatic 22.45 per cent, and demographic factors 13.92 per cent. The values of vulnerability indices varied from 0.30 (Madhepura) to 0.59 (Kishanganj) in 1996-2005 indicated that there was a wide variability in the factors influencing climate change. In the year 2006-2015, the district of Supaul replaced Kishanganj from the first position with reference to overall vulnerability to climate change. Kisanganj was remains in first position with respect to sensitivity component of vulnerability. The degree of vulnerability of Kisanganj district was again placed under highly vulnerable district; however the district of Supaul, Saharsa, Madhepura, Purnea and Khagaria were placed under moderate vulnerability and the district of Araria was considered as least vulnerable district amongst all the selected district under study so far. Its range of vulnerability was varied from $\leq$ 28.58.Therefore climate change policies have to be integrated with sustainable development strategy such as social control, pollution control, as well as emphasis towards regional crop planning for most Vulnerable district of Kosi region of Bihar. Since the worst sufferers of climate change impacts are the rural communities, (who depends mainly on agriculture as their livelihoods), it is important to focus on the impacts of climate change on livelihoods, and re-establish the links among poverty, livelihood and environment. However, focusing on the community's only are not enough, and so long as the community initiatives do not become part of the government policies, it is difficult to sustain the efforts. Thus, the link between local, state and national governments to the community is of utmost importance.

\section{Introduction}

'Vulnerability' is usually associated with natural hazards like floods, droughts, and social hazards. However, with increased importance in climate change research, it has been widely used to compute vulnerability.
The Intergovernmental Panel on climate change (IPCC) has defined vulnerability as the degree to which a system is susceptible to, or unable to cope with, adverse effects of climate change, including climate variability 
and extremes (McCarthy et al., 2001).vulnerability has been related or equated to concepts such as resilience, marginality, susceptibility, adaptability, fragility, and risk" (Liverman, 1990). The small and marginal farmers, in particular, are more vulnerable to both the current and future climate change impacts, given their high dependence on agriculture, strong reliance on ecosystem and rapid population growth. Year to year variability in climate contributes to rural poverty where the exposure is high and adaptive capacity is low. The effects of climatic on farming is prominent as it has been observed as delayed sowing, changes in cropping patterns, higher infestation of pest and diseases, less availability of water for irrigation, reduced profits due to increased prices of inputs and wages as well as stagnation of output prices, shift towards nonfarm occupations, migration, etc. Vulnerability captures notions of possible loss, damage, and impact of threat risk and stress of uncertainty and insecurity of a lack of power and control; and of a number of other factors that contribute to a feeling or state of being vulnerable. Climate change is the biggest threat to livelihood security and the development of human capabilities. The rural people are more vulnerable to climate changes owing to their heavy dependence on agriculture for food and livelihood. For preparing people to face these challenges, decision-makers and policy planners need aclose assessment of the vulnerability i.e. the degree to which agriculture is susceptible to the adverse effects of climate change, including climate variability and extremes is needed to allocate resources effectively and reduce the impacts. Vulnerability is a function of rate of climate variation to which a system is exposed, its sensitivity and its adaptive capacity. Thus, vulnerability has three components: exposure, sensitivity and adaptive capacity. These three components are described as follows: 1) Exposure can be interpreted as the direct danger (i.e., the stressor) and the nature and extent of changes to a region's climate variables (e.g. temperature, precipitation, extreme weather events). ii) Sensitivity describes the humanenvironmental conditions that can worsen the hazard, ameliorate the hazard, or trigger an impact. iii) Adaptive capacity represents the potential to implement adaptation measures that help avert potential impacts. Due to its adverse impacts, climate change has always been a matter of great concern to the farming, scientific and developmental communities. Climatic extreme events together with an increase in rates of change in climatic parameters could affect various sectors including water, agriculture, health, tourism, transport, energy etc. In the future, the climate change associated impacts are imminent with the anticipated vagaries of the weather. The impacts of climate change would add an additional burden to the poor smallholder farmers in developing country.

\section{Importance of study in Bihar}

Vulnerability to climate change is closely related to poverty as the poor are least able to respond to climate change. To cope up with changes in the production system virtual stagnation of the crop yield, floods, droughts, heat/cold waves etc. are various forms of disasters prevalent in the state. Among natural disasters, flood is the most common and a regular phenomenon in Bihar resulting in enormous loss of life and property. In addition to floods, Increasing population pressure, high density of buildings and their poor construction quality, the settlement in vulnerable areas and inadequate or no investment on mitigation/ Preparedness measures has further increased the vulnerability need to be assessed. The Kosi is one of the major tributaries of the Ganga River, and rises in the Nepal Himalayas (Mishra, 1997). This study has been planned 
to compare the vulnerability among districts over the period of time, keeping in view the extent of damage due to natural calamities and other parameters like social, economic, occupation, climate and demographic etc. directly or indirectly responsible for vulnerability to agriculture and also need to know which factors or sources should be strengthen as no study related to vulnerability has been carried out for kosi region of Bihar.

\section{Materials and Methods}

The study was conducted in Kosi region of Bihar to compare the vulnerability indices of different sources of vulnerability in selected district of Kosi region of Bihar. The study was mainly based on secondary data for the period from 1976 to 2015 and was collected from various published source like Indian Meteorology Departments (IMD), DES, Patna, Ministry of Agriculture, Govt. of India. Keeping in view the availability of data, 8 districts (Supaul, Saharsa, Madhepura, Araria, Purnia, Katihar, Khagaria, and Kishanganj) of Kosi region of Bihar were selected.

The simple average method, Patnaik and Narayanan's method of equal weight were used to compute vulnerability; however degree of vulnerability was also assessed using expert judgement method which was based on expert opinion with different weight on variables.

In order to obtain the value free from the units, they were normalized so that they all lie between 0 and 1 .

Before normalization, factors associated with vulnerability were identified and their functional relationship was found out using the collected secondary data of different years/censuses data on selected variables. Normalization was usually done of the variables having increasing/decreasing functional relationship with vulnerability with the formula

$$
\mathrm{U}_{\mathrm{ij}}=\frac{\mathrm{X}_{\mathrm{ij}}-\mathrm{Min} \mathrm{X}_{\mathrm{ij}}}{\operatorname{Max} \mathrm{X}_{\mathrm{ij}}-\operatorname{Min} \mathrm{X}_{\mathrm{ij}}} \ldots \ldots \ldots \ldots \ldots
$$

Where,

$\mathrm{X}_{\mathrm{ij}}$ is the value assigned by $\mathrm{i}^{\text {th }}$ respondent on $\mathrm{j}^{\text {th }}$ component

Min $\mathrm{X}_{\mathrm{j}}$ is minimum score on $\mathrm{j}^{\text {th }}$ component

$\operatorname{Max} \mathrm{X}_{\mathrm{j}}$ is maximum score on $\mathrm{j}^{\text {th }}$ component $\mathrm{U}_{\mathrm{ij}}$ is unit value of $\mathrm{i}^{\text {th }}$ respondent on $\mathrm{j}^{\text {th }}$ component

And for those variables have decreasing functional relationship with vulnerability the normalization was done by using the formula respectively.

$$
\mathrm{U}_{\mathrm{ij}}=\frac{\operatorname{Max} X_{\mathrm{ij}}-\mathrm{X}_{\mathrm{ij}}}{\operatorname{Max} \mathrm{X}_{\mathrm{ij}}-\operatorname{Min} \mathrm{X}_{\mathrm{ij}}}
$$

After computing the normalized scores the index was constructed and compare at a point of time as well as by using equal weights to all indicators/components or unequal weights to all the variables responsible for vulnerability.

\section{Simple average of the scores}

All the normalized scores given equal importance to all the variables to construct the vulnerability indices for eight districts selected by using the formula:

$\mathbf{V I}=\frac{\sum_{\mathbf{j}} \mathbf{U}_{\mathrm{ij}}}{\mathbf{k}}$

Finally, the vulnerability indices were used to rank the different districts in terms of vulnerability. A region with highest index was said to be most vulnerable and it is given the rank1, and vice- versa. 
Patnaik and Narain method (Patnaik and Narayanan, 2005)

In this method, several sub-indicators/sources were identified as 1. Demographic, 2.Climatic, 3.Agricultural 4.Occupational, after normalization, the average index (AI) for each source of vulnerability was worked out and then the overall vulnerability index was computed by employing the following formula:

$\mathbf{V I}=\frac{\left[\sum_{i=1}^{n}\left(\mathrm{~A} \mathbf{I}_{\mathrm{i}}\right)^{\alpha}\right]^{\frac{1}{\alpha}}}{\mathbf{n}}$

Where, $\mathrm{AI}=$ Average index, $n$ is the number of sources of vulnerability and $\alpha=n$.

After analysing the values of the indices of all the districts for different period of time they were compared to identify the most vulnerable districts in terms of the indicators used for measurement.

\section{Expert judgement method}

The experts of concerned field were asked to rank these four components in the descending order according to their relative importance. Garrett's ranking technique was used to reveal the importance of each component based on their unit value after normalization. The percentage positions thus obtained were transformed into scores on a scale of 100 points by using Garrett's table. From the scores, the average score was derived.

This is termed as scale value $(\mathrm{Sj})$ of each component. The unit values (Uij) for each combinations and category of experts were multiplied by respective component scale value, summed up and divided by total scale value to get vulnerability Index (VI) of each of the combinations in different categories of experts. The value of SI is in percentage.
Higher the VI higher will be the vulnerability of that district (Rahaman et al., 2016)

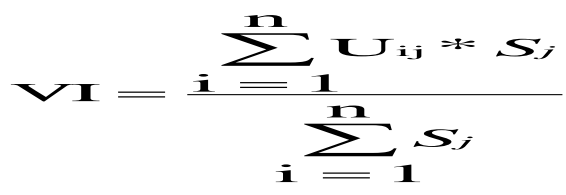

\section{Garrett's ranking technique}

Scores of individual respondents were added together and then divided by total number of respondents. Thus, mean score for each constraint was ranked by arranging them in descending order.

Percentage position $=\frac{100\left(\mathrm{R}_{\mathrm{ij}}-0.50\right)}{\mathrm{N}_{\mathrm{j}}}$

Where, $\mathrm{R}=$ Rank given for the $\mathrm{i}$ item by the $\mathrm{j}$ individual and

$\mathrm{N}=$ Number of items ranked by the $\mathrm{j}$ individual.

Thus after constructing the vulnerability index by method of unequal weight, the different districts of Kosi region were categorized according to high, moderate and low in following way:

Highly vulnerable :> (Standard Deviation + Mean)

Low vulnerable :< (Standard Deviation Mean)

Moderately vulnerable: Between (Standard Deviation \pm Mean)

\section{Standard deviation}

It is found by taking the difference of each item in the series from arithmetic mean $(\overline{\mathrm{X}})$ squaring this difference: summing all squire difference's dividing by number of item and them extracting the square root or in a formula. 
$\mathrm{SD}=\sqrt{\frac{\sum(\mathrm{x}-\overline{\mathrm{x}})^{2}}{\mathrm{n}-1}}$

Where, $\mathrm{x}=$ observation, $\overline{\mathrm{x}}=$ Arithmetic mean of the population, $\mathrm{n}=$ Number of given observation and $\mathrm{x}-\overline{\mathrm{x}}=$ Deviation from the mean

\section{Results and Discussion}

Vulnerability is a function of the character, magnitude, and rate of change in stresses to which a system is exposed, its sensitivity, its ability to adaptation or adaptive capacity. Therefore to compute indices sources responsible for vulnerability need to be identified. The sources and indicators of vulnerability identified and their functional relationship are presented in tables 1 and 2 .

Vulnerability indices suggested many important hypotheses relating the vulnerability of the districts to climate change with different indicators as socio-economic, climatic agricultural and occupational indicators and has been presented in table 3 .

\section{The density of population}

District influenced its demographic vulnerability and was hypothesised to be positively related to the vulnerability to climate change, i.e., with the increase in the number of persons per sq. km., the vulnerability to climate change would increase due to its direct impact on global warming. This would be due to increased pollution and Green House Gas (GHG) emissions as a result of greater use of vehicles, rapid use of non-renewable and other natural resources, greater use of nonbiodegradable materials like polythene, etc. For the people there would be increase in illness and diseases, shortage of natural resources such as water, land, food, shortage of infrastructure such as medical facilities/medications etc. Moreover, any occurrence of extreme events, viz., droughts, floods etc. is likely to be more catastrophic for the people living in these districts (Patnaik and Narayanan, 2005).

\section{The literacy rate}

On the other hand, was hypothesised to have a negative functional relationship with demographic vulnerability and thereby, on the overall vulnerability to climate change. Literacy rate indicated the adaptability of the population to both adverse impacts caused by shocks and the opportunities created. It also implies the proportion of expenditure on education in total public expenditure which indicates investment in human capital. It was seen that a high value of this variable implied more literates in the region and so greater awareness to cope up with climate change impacts (Palanisami et al., 2009)

\section{Climatic vulnerability}

It was assumed to be positively related to the indicators such as variances in annual rainfall as well as minimum and maximum temperature variances, indicated that any increase in the variability of these climatic indicators would increase the vulnerability of the districts to climate change. Glantz and Wigley (1986) studied the worldwide climate change and showed that any change in climatic variables like temperature and precipitation could induce vulnerability of food production in a major way.

\section{Yield is more uncertain}

Yield is more uncertain with unfamiliar technology. However, it could be seen that higher yields of crops led to higher incomes of the farmers and thereby increasing their risk bearing ability to various shocks. An 
increase in the livestock population per gross cropped area also results in an increase in the farmer's incomes through various animal husbandry based activities, thereby its negative functional relationship towards vulnerability. Similarly, the percentage of total food crops and non-food crops, the cropping and irrigation intensities and the net sown area in the district, each of these comprising the agricultural indicators, were also hypothesised to have a negative influence on the vulnerability to climate change. Lastly, all the occupational indicators were hypothesised to have a negative functional relationship to climate change as greater employment meant more secure incomes which would in turn increase the risk bearing capacities of the people.

\section{Comparative analysis of indicators of selected districts of Bihar}

The quantification of vulnerability of different factors, i.e. the density of population (Persons $/ \mathrm{km}^{2}$ ) was maximum in Khagaria district (male 23.05 and female 19.95) followed by Saharsa (male 22.32 and female 17.89) however it was minimum in Katihar district. Data pertaining to Literacy rate (\%) was estimated maximum again in Khagaria (male 48.51 and female 32.16) followed by Kisanganj (male45.56 and female 37.98) and minimum literate people were in Supaul district. Under the climatic factors the Kishanganj district had maximum rainfall and considered as most vulnerable district on the basis of recorded rainfall of $2175 \mathrm{~mm}$ and maximum temperature was $\left({ }^{\circ} \mathrm{C}\right) \quad$ (38.21) followed by Araria, Khagaria and least vulnerable district was Katihar (1233mm). On an account of agricultural vulnerability Production of food grains (tones/ha.) was maximum in Saharsa followed by Katihar (149551), Supaul and least production of food grains was in Khagaria district (103046). Productivity of food grains (tones/ha) Katihar is maximum (1.37) and was minimum in
Madhepura was 1.03. Livestock population (no./ha of net sown area) was maximum in Araria district (3.71) followed by Purnea, Supaul and least livestock population was in Khagaria district. However only relates to these parameter with mean data of censuses is not enough to compare the vulnerability. Therefore to analyze the data of associated factors over different period of time all the data of different parameter arranged accordingly and indices were computed after normalization.

The results of temporal vulnerability indices as well as component-wise contributions to the overall vulnerability to climate change for selected districts of Kosi region by using simple score method (Supaul, Saharsa, Madhepura, Araria, Purina, Katihar, Khagaria, Kishanganj) over different period have been presented and compared in table 3 .

Comparative analysis of vulnerability to climate change over different period indicated that, in period I (1976-85) period II and period IV (2006-2015) the value of vulnerability index was comparatively more than that of period III. It means higher the value of indices greater will be the vulnerability. District wise vulnerability indices indicated that among selected district Kisangang followed by Khagaria and Supaul was found to be most vulnerable district and Katihar, Araria followed by Saharsa was ranked as comparatively less vulnerable district. It may be concluded that those district which is found to be most vulnerable has lower adaptive capacity (agricultural component) and most sensitive towards the danger (climatic component) and vice-versa. If we look on the data over the different period the vulnerability in previous decade causes more severe damage to the life compared to rest of periods, thereafter due to change in the level of adaptive capacity vulnerabity to agriculture was less. 
Table.1 Sources and indicators of vulnerability

\begin{tabular}{|c|c|c|c|c|}
\hline Indicators & $\begin{array}{l}\text { Demographic } \\
\text { vulnerability }\end{array}$ & $\begin{array}{c}\text { Climatic } \\
\text { vulnerability }\end{array}$ & $\begin{array}{l}\text { Agricultural } \\
\text { vulnerability }\end{array}$ & $\begin{array}{l}\text { Occupational } \\
\text { vulnerability }\end{array}$ \\
\hline $\begin{array}{l}\text { Sub } \\
\text { indicators }\end{array}$ & $\begin{array}{l}\text { 1.Density of } \\
\text { population } \\
\text { 2.Literacy rate }\end{array}$ & $\begin{array}{l}\text { 1.Variance in } \\
\text { annual rainfall } \\
\text { 2. Variance in mean } \\
\text { 3.Maximum and } \\
\text { minimum temperature }\end{array}$ & $\begin{array}{l}\text { 1.Productivity of } \\
\text { major crops } \\
\text { 2.Cropping } \\
\text { intensity } \\
\text { 3.Area under } \\
\text { cultivation } \\
\text { 4.Irrigation } \\
\text { intensity } \\
\text { 5.Livestock } \\
\text { population, etc }\end{array}$ & $\begin{array}{l}\text { 1.Total workers } \\
\text { 2.Agricultural } \\
\text { labourer's } \\
\text { 3.Industrial } \\
\text { workers } \\
\text { 4.Cultivators } \\
5 \text { Non- workers, }\end{array}$ \\
\hline
\end{tabular}

Table.2 Functional relationship of indicators

\begin{tabular}{|c|c|c|c|c|}
\hline $\begin{array}{l}\text { Sl. } \\
\text { No. }\end{array}$ & Components & \multicolumn{2}{|r|}{ Indicators } & $\begin{array}{l}\text { Functional } \\
\text { Relationship }\end{array}$ \\
\hline \multirow[t]{3}{*}{1.} & \multirow[t]{3}{*}{ Demographic } & $\mathrm{a}$ & Density of population (persons per sq. km) & $\uparrow$ \\
\hline & & $\mathrm{b}$ & Literacy rate (per cent) & $\downarrow$ \\
\hline & & $\mathrm{c}$ & Infant mortality rate(death/'000infants) & $\uparrow$ \\
\hline \multirow[t]{4}{*}{2.} & \multirow[t]{4}{*}{ Climatic } & $\mathrm{a}$ & Variance of annual rainfall $(\mathrm{mm})$ & $\uparrow$ \\
\hline & & $\mathrm{b}$ & Variance of minimum temperature $\left({ }^{\circ} \mathrm{C}\right)$ & $\uparrow$ \\
\hline & & $\mathrm{c}$ & Variance of maximum temperature $\left.{ }^{\circ} \mathrm{C}\right)$ & $\uparrow$ \\
\hline & & d & Variance of diurnal temperature $\left.{ }^{\circ} \mathrm{C}\right)$ & $\uparrow$ \\
\hline \multirow[t]{4}{*}{3.} & \multirow[t]{4}{*}{ Agricultural } & $\mathrm{a}$ & Total food grains $(\mathrm{Kg} / \mathrm{ha})$ & $\downarrow$ \\
\hline & & $\mathrm{b}$ & Productivity of major crops $(\mathrm{Kg} / \mathrm{ha})$ & $\downarrow$ \\
\hline & & $\mathrm{c}$ & Cropping intensity (per cent) & $\downarrow$ \\
\hline & & d & $\begin{array}{l}\text { Livestock population (number per hectare of gross } \\
\text { cropped area) }\end{array}$ & $\downarrow$ \\
\hline \multirow[t]{5}{*}{4.} & \multirow[t]{5}{*}{ Occupational } & $\mathrm{a}$ & Number of cultivators (per hectare of net sown area) & $\downarrow$ \\
\hline & & $\mathrm{b}$ & Agricultural labourers (per hectare of net sown area) & $\downarrow$ \\
\hline & & $\mathrm{c}$ & Industrial workers (per hectare of net sown area) & $\downarrow$ \\
\hline & & $\mathrm{d}$ & total workers (per hectare of net sown area) & $\downarrow$ \\
\hline & & $\mathrm{e}$ & Non-workers (per hectare of net sown area) & $\downarrow$ \\
\hline
\end{tabular}

Table.3 Comparative analysis of vulnerability indices during 1976-2015

\begin{tabular}{|c|c|c|c|c|c|c|c|c|c|c|}
\hline District & \multicolumn{2}{|c|}{ P-I (1976-85) } & \multicolumn{2}{c|}{ P-II (1986-95) } & \multicolumn{2}{c|}{ P-III(1996-05) } & \multicolumn{2}{c|}{ P-IV(2006-15) } & \multicolumn{2}{c|}{$1976-2015$} \\
\hline & Index & Rank & Index & Rank & Index & Rank & Index & Rank & Index & Rank \\
\hline Kishanganj & 0.89 & 1 & 0.89 & 1 & 0.024 & 1 & 0.59 & 1 & 0.81 & 1 \\
\hline Khagaria & 0.78 & 2 & 0.8 & 2 & 0.021 & 3 & 0.51 & 4 & 0.8 & 2 \\
\hline Supaul & 0.53 & 7 & 0.57 & 5 & 0.021 & 2 & 0.54 & 2 & 0.67 & 3 \\
\hline Purnea & 0.6 & 4 & 0.61 & 3 & 0.019 & 4 & 0.52 & 3 & 0.57 & 4 \\
\hline Madhepura & 0.58 & 5 & 0.46 & 8 & 0.012 & 8 & 0.3 & 8 & 0.56 & 5 \\
\hline Saharsa & 0.63 & 3 & 0.61 & 4 & 0.014 & 7 & 0.37 & 6 & 0.56 & 6 \\
\hline Araria & 0.42 & 8 & 0.5 & 6 & 0.015 & 6 & 0.36 & 7 & 0.37 & 7 \\
\hline Katihar & 0.57 & 6 & 0.46 & 7 & 0.016 & 5 & 0.38 & 5 & 0.36 & 8 \\
\hline
\end{tabular}

Source: Field Survey, 2016 
Table.4 Component -wise percentage contribution of vulnerability indices during 1976 -2015

\begin{tabular}{|l|l|l|l|l|l|l|}
\hline District & Demographic & Climate & Agrl. & Occupational & Overall & Rank \\
\hline Kishanganj & 6.71 & 10.52 & 46.18 & 36.59 & 12.98 & 1 \\
\hline Khagaria & 13.2 & 14.82 & 36.62 & 35.35 & 12.85 & 2 \\
\hline Supaul & 11.32 & 20.52 & 25.53 & 42.64 & 10.69 & 3 \\
\hline Purnea & 20.35 & 26.72 & 36.22 & 16.71 & 9.12 & 4 \\
\hline Madhepura & 17.37 & 24.57 & 22.62 & 35.44 & 9.00 & 5 \\
\hline Saharsa & 19.36 & 16.07 & 32.42 & 32.14 & 8.99 & 6 \\
\hline Araria & 9.75 & 24.48 & 42.67 & 23.1 & 5.89 & 7 \\
\hline Katihar & 36.13 & 27.92 & 23.43 & 12.53 & 5.83 & 8 \\
\hline Overall & 15.42 & 19.41 & 33.92 & 31.25 & 100 & \\
\hline
\end{tabular}

Source: Compiled by the authors 2016

Table.5 Spatial and temporal distribution of vulnerability in selected districts of Bihar

\begin{tabular}{|l|l|l|l|l|l|l|l|l|l|l|}
\hline Year & \multicolumn{2}{c|}{$(1976-1985)$} & \multicolumn{2}{c|}{$(1986-1995)$} & \multicolumn{2}{c|}{$(1996-2005)$} & \multicolumn{2}{l|}{$(2006-2015)$} & \multicolumn{2}{l|}{$1976-2015$} \\
\hline District & V.I & Rank & V.I & Rank & V.I & Rank & V.I & Rank & V.I & Rank \\
\hline Kishanganj & 0.63 & 1 & 0.67 & 1 & 0.71 & 1 & 0.7 & 1 & 0.6 & 1 \\
\hline Khagaria & 0.64 & 2 & 0.65 & 2 & 0.65 & 2 & 0.6 & 2 & 0.6 & 2 \\
\hline Supaul & 0.47 & 4 & 0.45 & 5 & 0.45 & 5 & 0.5 & 5 & 0.4 & 5 \\
\hline Purnia & 0.41 & 6 & 0.48 & 3 & 0.48 & 3 & 0.5 & 3 & 0.4 & 4 \\
\hline Madhepura & 0.42 & 5 & 0.44 & 6 & 0.46 & 4 & 0.5 & 6 & 0.5 & 3 \\
\hline Saharsa & 0.51 & 3 & 0.47 & 4 & 0.45 & 6 & 0.5 & 4 & 0.3 & 6 \\
\hline Araria & 0.31 & 8 & 0.38 & 7 & 0.35 & 7 & 0.3 & 7 & 0.3 & 7 \\
\hline Katihar & 0.34 & 7 & 0.31 & 8 & 0.32 & 8 & 0.3 & 8 & 0.3 & 8 \\
\hline
\end{tabular}

(Source: compiled by the authors)

Table.6 Component wise analysis of vulnerability indices by

Expert judgement method (1976-2015)

\begin{tabular}{|l|c|c|c|c|c|c|}
\hline District & Exposure & & Sensitivity & & $\begin{array}{c}\text { Adaptive } \\
\text { capacity }\end{array}$ & \\
\hline & yij & Rank & yij & Rank & yij & Rank \\
\hline Kishanganj & 38.82 & 6 & 62.45 & 1 & 85.57 & 1 \\
\hline Khagaria & 45.11 & 4 & 51.49 & 3 & 76.81 & 2 \\
\hline Supaul & 55.62 & 2 & 17.5 & 8 & 58.57 & 3 \\
\hline Purnia & 61.01 & 1 & 50.54 & 4 & 39.53 & 6 \\
\hline Madhepura & 53.88 & 3 & 46.91 & 5 & 50.6 & 4 \\
\hline Saharsa & 37.22 & 7 & 19.45 & 7 & 46.46 & 5 \\
\hline Araria & 36.23 & 8 & 59.54 & 2 & 26.38 & 7 \\
\hline Katihar & 41.83 & 5 & 35.38 & 6 & 22.3 & 8 \\
\hline
\end{tabular}


Table.7 Comparative analysis of degree of vulnerability for the period (1976-2015): Ranking of indicators using expert judgement method during 1996 - 2005

\begin{tabular}{|l|l|l|}
\hline Scale & Level & Name of district \\
\hline Exposure & Highly & Kishanganj \\
\hline$\geq 47.744$ & Moderate & Supaul, Saharsa, Madhepura, Khagaria, Purnea, Araria \\
\hline $26.82-47.74$ & Least & Katihar \\
\hline$\leq 26.82$ & Highly & Purnea,Katihar \\
\hline Sensitivity & Moderate & Saharsa, Madhepura, Kishanganj, Khagaria, Araria \\
\hline$\geq 66.2866 .28$ & Least & Supaul \\
\hline $36.79-66.28$ & Highly & Kishanganj \\
\hline$\leq 36.79$ & Moderate & Supaul, Saharsa, Madhepura, Araria, Purnea, Khagaria \\
\hline Adaptive Capacity & Least & Katihar \\
\hline$\geq 73.58$ &
\end{tabular}

Source: Field Survey, 2016

Component wise analysis of vulnerability indices

Component wise vulnerability during 1975 2015 indicated that agriculture and occupational vulnerability were contributing more i.e. 34 per cent and 31 per cent respectively to the climate change (Table 4). Other factors were the climate and demographic contributed 19.41 per cent and 15.42 per cent respectively. Data pertaining to district wise analysis of different identified factors indicated that, in Kishanganj district agricultural vulnerability (46\%) ranked one and considered as most vulnerable districts from the point of farming followed by occupational vulnerability in the district of Supaul. However demographic vulnerability was contributing maximum in Katihar and minimum in Kisanganj. As far as climatic vulnerability was concerned, the district which was considered as highly vulnerable was Katihar and Purnea; however Kisangani was least vulnerable due to climatic variables. Other sources of vulnerability were occupational vulnerability and it contributed maximum in Supaul and minimum in Katihar districts. It may be concluded that, among four indicators of vulnerability to climate change agriculture vulnerability followed by occupational indicators were the major indicators of climate change. However climatic factors were the third factor which affects the vulnerability to climate change. It clearly indicated that agricultural vulnerability was most common phenomenon in selected districts of Bihar over the reference period. Climate played important role in production of crop therefore strategies for selection of crop according to the prevailing situation as well selection of suitable subsidiary enterprises to cope with the existing situation is need of hour. To check out migration suitable policy related to employment generation for rural youth is also need of hours, because to mitigate the challenges engagement of rural youth in agriculture is necessary (Table 6).

In spatial and temporal assessment of vulnerability from the period (1976-1985, 1986-1995, 1996-2005 and 2006-2015), the district of Kisanganj was the most vulnerable district followed by Khagaria and Supaul stood at the second and third position, respectively (Table 5). Further it may 
revealed that except in first period district Purnia was ranked third but overall Madhepura was the third vulnerable district in the spatial assessment of vulnerability. The district Katihar was ranked as least vulnerable district in all most all mentioned period. It was due to the fact that variances in annual rainfall as well as minimum and maximum temperature variances, of Katihar shown minimum variability, if any increase in the variability of these climatic indicators would increase the vulnerability of the districts to climate change. Productivity of food grains (tones/ha) was also found maximum (1.37) in Katihar. The Research station played a greater role in the transfer of technology to the farmer's door for enhancing crop productivity. Similarly, adoption of subsidiary enterprises on a mass scale also led to change in the agricultural scenario in the district.

\section{Expert judgement method}

The component of vulnerability included for computing vulnerability in this method were (i) Exposure (ii) Sensitivity and (iii) Adaptive capacity. The vulnerability indices over the period (1976-1985) due to exposure indicated that Araria was considered as highly vulnerable district followed by Saharsa and Supaul and least vulnerable district was Katihar. Due to sensitivity, Saharsa was highly vulnerable district and least vulnerable district was Kisanganj. However due to adaptive capacity, Kishanganj was highly vulnerable and Araria was considered as the least vulnerable district of Kosi region of Bihar.

In the Period (1986-1995) Araria district was highly vulnerable (60.28) due to exposure and least vulnerable district was Katihar. However due to sensitivity, Purniea was highly vulnerable and Supaul was considered as the least vulnerable district of Bihar. However impact of adaptive capacity on vulnerability, indicated that Kishanganj and Khagaria was ranked as highly vulnerable and Katihar and Araria were ranked as least vulnerable district. In (1996-2005) highly vulnerable district due to exposure was Kishanganj ( $\geq$ 47.74) followed by Araria and Purnia. Due to sensitivity, Purnia was the most and Supaul was the least vulnerable district and due to influence of adaptive capacity, Kishanganj $(\geq 73.58)$ was most vulnerable district and Katihar was the least vulnerable district. In (2006-2015), the district of Purnia ranked first due to exposure and sensitivity and due to adaptive capacity Kishanganj was the highly vulnerable district and least vulnerable district due to exposure and adaptive capacity was Katihar and due to sensitivity, Supaul was the least vulnerable district. In the Period (19762015) highly vulnerable district to exposure was Purnia, however due to sensitivity and adaptive capacity Kishanganj was highly vulnerable district, because people of mentioned districts were not well enough about new technologies awareness of proper package and practices, in these districts for cultivation of crop (Table 7). Due to change in the temperature attack of disease and pest will be more causes declined in the productivity of crop. It may further reveal that there were no weather stations working properly in selected area under study. Subsidiary enterprises were also not given importance much by the people. Due to less literacy rate people were not able to handle the situation amicably i.e. coping mechanism was poor. Our state government have also identified these districts as vulnerable districts and established Agricultural College in Kisanganj.

Therefore, coping mechanism against the vulnerability for highly vulnerable district of Bihar need special attention.

In conclusion, Kosi region of Bihar is rapidly expanding its production and consumption 
activities. The region not only contributes to climate change but is equally vulnerable to its impacts. Since the agricultural sectors have the greatest bearing there is a need to shift focus towards investments in adaptation of basic research for these districts of Bihar. The occupational indicators were the second largest contributors towards overall vulnerability, thus, to reduce the climate change impact, the policy makers must focus on generating better employment opportunities including income diversification options for the people in the regions where the incidences of outmigration are high.

In highly vulnerable district policy makers should enact measures to support effective management of environmental resources, Adaptation policies should increase the resilience of farming and food systems to climate change impacts while maintaining or increasing food production.

For example- New cropping practices, timing of planting, Better use of short-term and seasonal climate forecasting to reduce production risks, Since the rural communities, (who depends mainly on agriculture as their livelihoods), are most affected due to climate change, it is important to focus on the impacts of climate change on livelihoods, and reestablish the links among poverty, livelihood and environment. And enact social programs and spending on health, education and welfare, which can help in maintaining and augmenting both physical and intangible human capital. Finally, investment should be made in the development of infrastructure in rural areas, and in high exposure regions, priority should be given to the development of more accurate systems for early warning of extreme climatic events (e.g., drought or flood) apart from appropriate relief programs and agricultural insurance. So kosi region of Bihar requires a development strategy that integrates climate change policies with sustainable development strategies to effectively combat climate change issues.

\section{References}

Adger WN, Brooks N, Bentham G, Agnew M and Eriksen S 2004. New indicators of vulnerability and adaptive capacity, Tyndall Centre Technical Report, No.7. Tyndall Centre for Climate Change Research, University of East Anglia, Norwich, UK.

Aggarwal, PK, Pathak H and Kumar N 2009. Global Climate Change and Indian Agriculture: A Review of Adaptation Strategies. Trust for Advancement of Agricultural Sciences, New Delhi, August 2009.

Blaikie P, Cannon T, David I and Wisner B 1994. At Risk: Natural Hazards, People's Vulnerability, and Disasters, London: Routledge.

Chamber R 1983. Rural Development: Putting the Last First, Essex: Longman

Chaturvedi RK, Kattumuri $\mathrm{R}$ and Ravindranath D 2014. Mainstreaming adaptation to climate change in Indian policy planning. International Journal of Applied Economics and Econometrics22 (1): 23-56.

Hiremath DB and Shiyani RL 2012. Evaluating regional vulnerability to climate change: a case of Saurashtra. Indian Journal of Agricultural Economics67 (3): 334-344.

Hiremath DB and Shiyani RL 2013. Analysis of vulnerability indices in various agroclimatic zones of Gujarat. Indian Journal of Agricultural Economics68 (1): 122-137.

Iyenger NS and Sudarshan P 1982. A Method of Classifying Regions from Multivariate Data. Economic and Political Weekly 17 (51): 48-52.

Mall RK, Singh R, Gupta A, Srinivasan G and Rathore LS 2006. Impact of Climate Change on Indian Agriculture: A Review. Climatic Change78: 445-478. 
McCarthy JJ, Canziani OF, Leary NA, Dokken DJ and White KS (Eds.) 2001. Climate Change: Impacts, Adaptation and Vulnerability, Cambridge University Press, Cambridge.

Mishra DK 1997. The Bihar Flood Story. Economic and Political Weekly30 (18): 2206-2217

BhartiJyoti, Kumari M, Rahman M, Meena L. K, Bairwa S.L(2017)Indian Journal of Ecology44 special issue(2):21-27.

Patnaik $\mathrm{U}$ and Narayanan $\mathrm{K}$ 2005.Vulnerability and Climate Change: An Analysis of the Eastern Coastal Districts of India. Paper was presented in an international workshop on "Human Security and Climate
Change" at Holmen Fjord Hotel, Asker, near Oslo, on 21-23 June 2005.

Sharma, U. and Patwardhan, A (2007) Methodology for identifying vulnerability hotspots to tropical cyclone hazard in India.

UNDP (2006) Human development report, United Nations Development Program. Available at: http://hdr.undp.org/hdr2006/statistics/.

Watson, R.T., M.C. Zinyowera and R.H. Moss, 1996. "Climate Change 1995: Impacts, Adaptations and Mitigation of Climate Change: Scientific-Technical Analyses", Cambridge University Press, Cambridge.

\section{How to cite this article:}

Meera Kumari and Jyoti Bharti. 2017. Comparative Analysis of Vulnerability Indices and its Implications: A Case of Kosi Region (Bihar). Int.J.Curr.Microbiol.App.Sci. 6(7): 1062-1073. doi: https://doi.org/10.20546/ijcmas.2017.607.128 